\title{
MODEL MENTAL DAN KEMAMPUAN SPASIAL MAHASISWA TAHUN PERTAMA DAN KETIGA PENDIDIKAN KIMIA DI UNIVERSITAS MATARAM
}

\section{MENTAL MODELS AND SPATIAL ABILITY OF THE FIRST AND THIRD YEAR CHEMISTRY EDUCATION STUDENTS AT UNIVERSITY OF MATARAM}

\author{
Supriadi*, Wildan, Aliefman Hakim, L. R. Telly Savalas dan Mukhtar Haris \\ Program Studi Pendidikan Kimia, FKIP, Universitas Mataram, Mataram, Indonesia \\ *Email: Supriadi_fkip@unram.ac.id
}

Diterima: 18 Januari 2021. Disetujui: 20 Mei 2021. Dipublikasikan: 2 Juni 2021

\begin{abstract}
Abstrak: Pembelajaran kimia yang lengkap menuntut mahasiswa untuk memahami materi kimia dengan menghubungkan tiga level representasi, yaitu representasi makroskopik, simbolik, dan submikroskopik. Kemampuan menghubungkan ketiga level representasi tersebut disebut dengan model mental. Model mental terdiri atas model mental saintifik, sintetik, dan inisial. Dalam mengembangkan model mental, dibutuhkan kemampuan spasial. Penelitian ini bertujuan untuk mengidentifikasi model mental dan kemampuan spasial mahasiswa pendidikan kimia tahun pertama dan tahun ketiga Universitas Mataram dan menganalisis hubungan antara model mental dan kemampuan spasial mahasiswa. Ini merupakan penelitian eksperimen semu. Data dianalisis menggunakan uji beda (uji t) dan uji regresi linear. Berdasarkan uji t, tidak ada perbedaan model mental antara mahasiswa tahun pertama dan tahun kedua dengan nilai signifikansi sebesar $0,861>0,05$. Selain itu, kemampuan spasial mereka juga tidak berbeda, yaitu dengan nilai signifikansi sebesar 0,328>0,05. Terdapat hubungan antara model mental dan kemampuan spasial mahasiswa. Sebagian besar mahasiswa tahun pertama $(81,25 \%)$ dan tahun ketiga $(79,5)$ memiliki kemampuan spasial sangat rendah. Selain itu, model mental dari sebagain besar mahasiswa tahun pertama dan tahun ketiga juga masih pada level paling rendah, yaitu level inisial. Hasil penelitian ini menunjukkan bahwa pembelajaran di kelas belum mampu meningkatkan kemampuan spasial dan model mental mahasiswa.
\end{abstract}

Kata kunci: Kemampuan spasial, model mental, multilevel representasi

\begin{abstract}
Complete chemistry learning requires students to understand chemistry by connecting three levels of representation, namely macroscopic, symbolic, and submicroscopic representations. The ability to relate these three levels of representation is called a mental model. Mental models consist of scientific, synthetic, and initial mental models. In developing mental models, spatial abilities are needed. This study aims to identify mental models and spatial abilities of the first and third year chemistry education students of University of Mataram and to analyze the relationship between mental models and students' spatial abilities. This is a quasi-experimental research. The data were analyzed using t-test and linear regression test. Based on the t-test, there was no difference in mental models between first and second year students with a significance value of $0.861>0.05$. In addition, their spatial abilities are not different, with a significance value of $0.328>0.05$. There is a relationship between students' mental models and spatial abilities. Most of the first year students (81.25\%) and third year students (79.5) have very low spatial abilities. Mental models of most of the first and third year students are still at the lowest level, namely the initial level. The results of this study indicate that classroom learning has not been able to improve students' spatial abilities and mental models.
\end{abstract}

Keywords: Spatial ability, mental model, multilevel representation

\section{PENDAHULUAN}

Pembelajaran kimia yang lengkap menuntut mahasiswa untuk memahami materi kimia dengan menghubungkan tiga level representasi, yaitu representasi makroskopik, simbolik, dan submikroskopik [1][2][3]. Representasi makroskopik diperoleh melalui pengamatan nyata dari suatu fenomena berupa warna, bentuk, aroma, dll. Representasi submikroskopik menjelaskan fenomena pada level partikulat. Representasi simbolik diperoleh melalui simbol-simbol level partiulat. Dari ketiga level representasi tersebut, mahasiswa sering kesulitan dalam memahami level submikroskopik karena bersifat abstrak (tidak dapat diobservasi) [4].

Kemampuan dalam menghubungkan ketiga level representasi disebut dengan model mental [2], [5]. Model mental terdiri atas model mental saintifik, sintetik, dan inisial. Model mental saintifik merupakan tingkatan tertinggi yang sesuai dengan konsep ilmiah. Pada model mental saintifik, mahasiswa mampu menggambarkan konsep kimia sampai pada level submikroskopik dan mampu menghubungkannya dengan level simbolik dan makroskopik. Jenis model mental yang kedua adalah model sintetik. Mahasiswa yang mengembangkan 
model mental sintetik mampu menggambarkan konsep kimia pada level submikroskopik, namun belum mampu menghubungkannya dengan level simbolik dan submikroskopik. Model yang paling rendah adalah model mental inisial. Pada model mental inisial, mahasiswa belum mampu menggambarkan konsep kimia pada level submikroskopik dan belum mampu menghubungkannya dengan level yang lain [4].

Menurut Cheng \& Gilbert [6], pembelajaran kimia diawali dengan mempelajari aspek makroskopik dan simbolik, kemudian diperdalam dengan aspek submikroskopik. Akan tetapi, Berdasarkan observasi terhadap pembelajaran kimia saat ini, masih ada pembelajaran yang mempelajari konsep kimia melalui aspek submikroskopik dan simbolik terlebih dahulu, kemudian mempelajari aspek makroskopik dengan cara mempraktikkannya di laboratorium. Bahkan, ada juga yang tidak menghubungkan ketiga level representasi, mahasiswa mempelajari konsep kimia hanya dengan cara submikroskopik dan simbolik saja tanpa menghubungkannya dengan aspek makroskopik. Menurut [7].

Pembelajaran kimia yang tidak menghubungkan ketiga level representasi kimia dapat menyebabkan rendahnya hasil belajar mahasiswa [8]. Hal ini disebabkan karena pemahaman mahasiswa tentang kimia tidak utuh. Menurut Chittleborough [9] semua fenomena kimia harus dijelaskan melalui tiga level representasi.

Selain model mental, kemampuan spasial juga dapat mempengaruhi hasil belajar [10], [11]. Dalam mempelajari kimia, mahasiswa menggunakan kemampuan spasial untuk mengubah rumus kimia menjadi struktur molekul [12]. Kemampuan spasial merupakan kemampuan mahasiswa dalam membayangkan bentuk tiga dimensi (3D) dari suatu objek [13]. Sebagai contoh, mahasiswa membuat bentuk 3D dari struktur molekul air.

Identifikasi model mental dan kemampuan spasial mahasiswa penting dilakukan untuk mengetahui tingkat pemahaman mahasiswa. Identifikasi ini dilakukan untuk mengetahui apakah terdapat miskonsepsi pada pemahaman mereka. Data model mental dan kemampuan spasial mereka digunakan sebagai dasar dalam mengembangkan media dan model pembelajaran untuk memperbaiki pemahaman konsep mereka. Jika model mental dan kemampuan spasial tidak diidentifikasi,, maka dosen tidak akan mengetahui kebutuhan dari mahasiswa tersebut.

Pembelajaran di Program Studi Pendidikan Kimia FKIP Universitas Mataram belum diuji pengaruhnya terhadap kemampuan spasial dan model mental untuk mengetahui kualitas dari pembelajaran yang diterapkan. Oleh karena itu, perlu dilakukan penelitian yang membandingkan kemampuan spasial mahasiswa tahun pertama yang belum pernah merasakan pembelajaran di kampus dengan mahasiswa tahun ketiga yang sudah merasakan pembelajaran di Program Studi Pendidikan Kimia FKIP Universitas Mataram selama kurang lebih tiga tahun. Hal ini dilakukan untuk mengetahui sejauh mana pembelajaran yang dilaksanakan berpengaruh terhadap model mental dan kemampuan spasial mahasiswa.

\section{METODE PENELITIAN}

Penelitian ini merupakan penelitian kuasi eksperimen dengan subyek penelitian yang digunakan adalah 48 mahasiswa baru dan 39 mahasiswa semester 6 tahun akademik 2020/2021. Data dikumpulkan menggunakan tiga instrument, yaitu tes model mental dan tes kemampuan spasial. Tes model mental berupa tiga butir pertanyaan terbuka dengan harapan bisa memperlihatkan gambaran kemampuan level makroskopik, submikroskopik, dan simbolik mahasiswa, serta kategori model mental yang mereka miliki karena siswa diberi keleluasaan dalam menyampaikan pendapatnya. Materi yang diuji pada tes model mental ini adalah tentang larutan. Tes kemampuan spasial terdiri atas tiga kemampuan, yaitu spatial visualization, spatial orientation, dan spatial relation sebanyak 30 butir soal pilihan ganda. Data dianalisis menggunakan analisis regresi berganda dan analisis secara deskriptif.

Rubrik penentuan kategori model mental diberikan pada tabel 1 berikut.

Tabel 1. Rubrik model mental mahasiswa

\begin{tabular}{cl}
\hline $\begin{array}{c}\text { Kategori } \\
\text { model mental }\end{array}$ & \multicolumn{1}{c}{ Isi } \\
\hline Model inisial & $\begin{array}{l}\text { Persepsi tidak sesuai dengan } \\
\text { pengetahuan ilmiah; jawaban belum } \\
\text { mencapai level submikroskopik }\end{array}$ \\
Model sintetik & $\begin{array}{l}\text { Persepsi Sebagian sesuai dan } \\
\text { sebagaian tidak sesuai dengan } \\
\text { pengetahuan ilmiah; jawaban sudah } \\
\text { mampu mencapai level } \\
\text { submikroskopik, namun belum } \\
\text { mampu menghubungkannya dengan } \\
\text { level makroskopik dan simbolik. } \\
\text { saintifik }\end{array}$ \\
& $\begin{array}{l}\text { Persepsi sesuai dengan pengetahuan } \\
\text { ilmiah; jawaban sudah mencapai } \\
\text { level submikroskopik dan mampu } \\
\text { menghubungkannya dengan level } \\
\text { makroskopik dan simbolik }\end{array}$ \\
\hline
\end{tabular}

Sumber: Altan Kurnaz \& Eksi [14]

Rubrik penentuan kategori kemampuan spasial diberikan pada tabel 2 berikut. 
Tabel 2. Rubrik kemampuan spasial mahasiswa

\begin{tabular}{cl}
\hline Skor & \multicolumn{1}{c}{ Kategori } \\
\hline $26-30$ & Sangat bagus \\
$24-25$ & Bagus \\
$22-23$ & Di atas rata-rata \\
$18-21$ & Rata-rata \\
$16-17$ & Di bawah rata-rata \\
$14-15$ & Rendah \\
$0-13$ & Sangat rendah \\
\hline & Sumber: Anggriawan et al. $[11]$
\end{tabular}

\section{HASIL DAN PEMBAHASAN}

Penelitian ini bertujuan untuk mengidentifikasi model mental dan kemampuan spasial mahasiswa pendidikan kimia tahun pertama dan tahun ketiga Universitas Mataram dan menganalisis hubungan antara model mental dan kemampuan spasial mahasiswa. Penelitian ini merupakan salah satu cara untuk mengetahui kualitas pembelajaran di Program Studi Pendidikan Kimia FKIP Universitas Mataram. Penelitian ini dibatasi hanya pada konsep larutan.

\section{Model Mental}

Terdapat tiga jenis model mental yang mungkin dikembangkan oleh mahasiswa, yaitu model inisial, model sintetik, dan model saintifik [14]. Namun dalam penelitian ini, mahasiswa belum mampu mengembangkan model saintifik dan bahkan sebagian besar mereka mengembangkan model yang paling rendah, yaitu model inisial. Sebagian besar mahasiswa, baik tahun pertama maupun tahun keempat menggambarkan larutan hanya sampai pada level simbolik. Mereka hanya menggunakan rumus kimia dalam menggambarkan bentuk molekul zat terlarut yang mana seharusnya digambar juga struktur tiga dimensinya.

Soal model mental yang diberikan dalam penelitian ini berupa pelarutan tiga jenis zat terlarut, yaitu zat elektrolit kuat, elektrolit lemah, dan nonelektrolit. Sebagian besar mahasiswa belum mampu menggambarkan larutan elektrolit lemah pada level submikroskopik. Mahasiswa menganggap partikel zat terlarut pada larutan elektrolit lemah mirip dengan elektrolit kuat, yaitu terionisasi sempurna. Contoh gambaran submikroskopik mahasiswa terkait larutan elektrolit kuat, elektrolit lemah, dan nonelektrolit diberikan pada gambar 1 berikut.

Mahasiswa yang mengembangkan model sintetik sudah mampu menggambarkan level submikroskopik, namun mereka tidak menghubungkannya dengan level makroskopik.

Berdasarkan data model mental mahasiswa, ada mahasiswa yang menganggap $\mathrm{NaCl}$ tetap berbentuk kristal dalam larutan, ada yang menganggap asam asetat tidak terionisasi, dan ada juga yang menganggap asam asetat terionisasi sempurna yang sama seperti $\mathrm{NaCl}$. Sebagian besar mahasiswa hanya menggambar ion asetat dan ion $\mathrm{H}^{+}$ dalam larutan asam asetat yang mana seharusnya ada juga asam asetat yang belum terionisasi karena dia merupakan elektrolit lemah. Menurut Suari, dkk. [15] anggapan tersebut merupakan miskonsepsi.

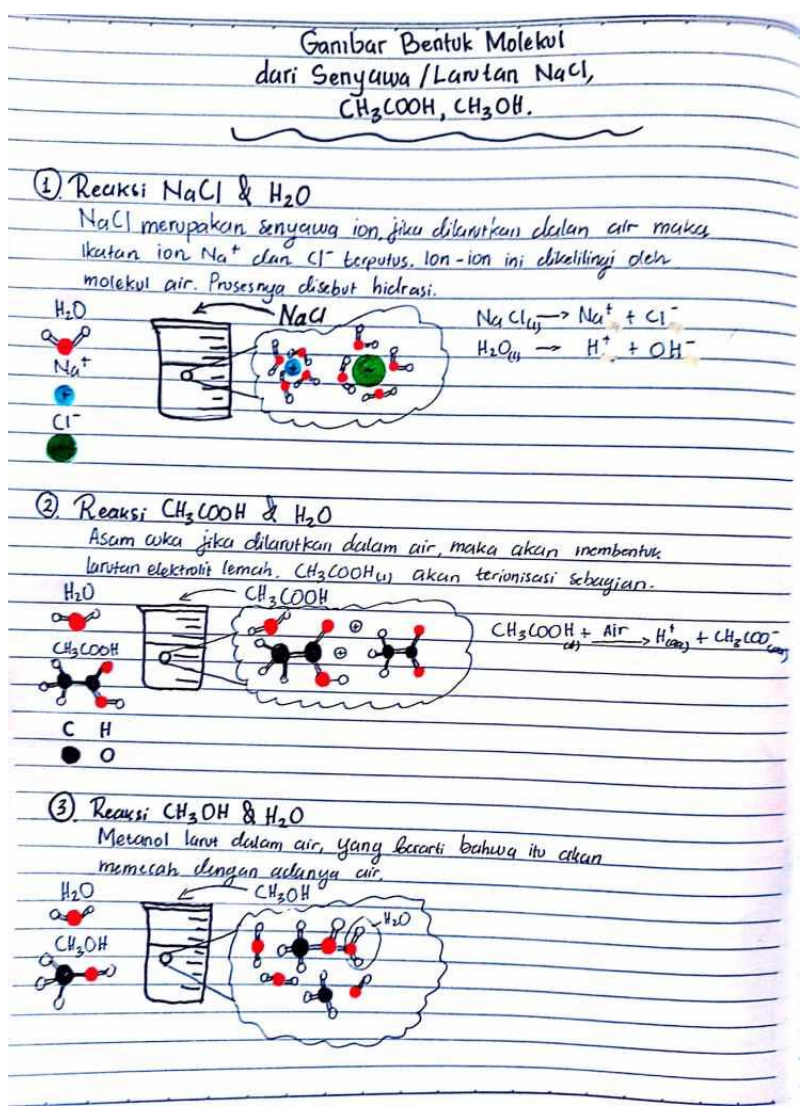

Gambar 1. Gambaran submikroskopik mahasiswa

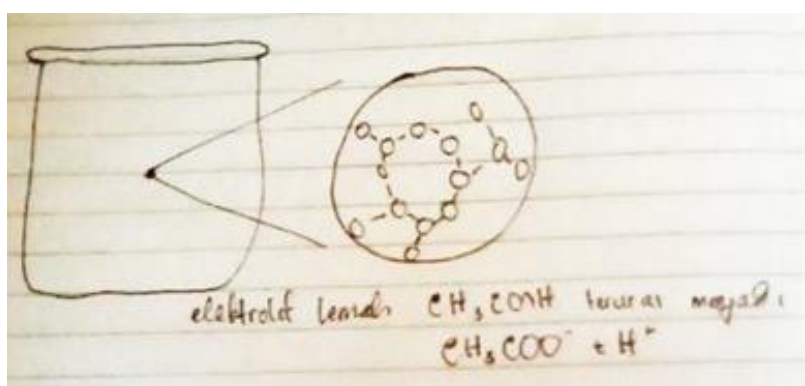

(a)

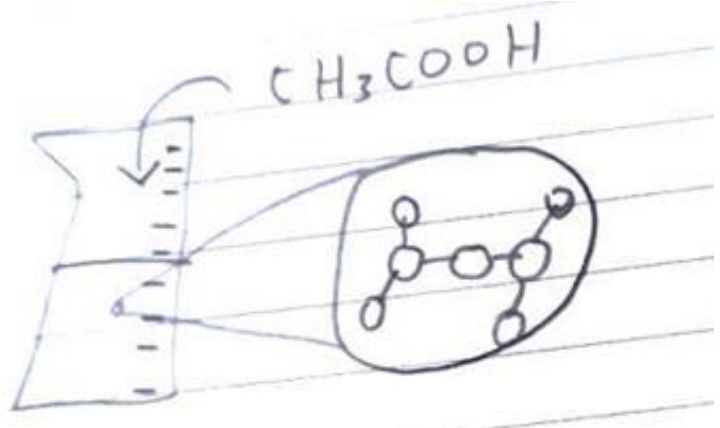

(b) 


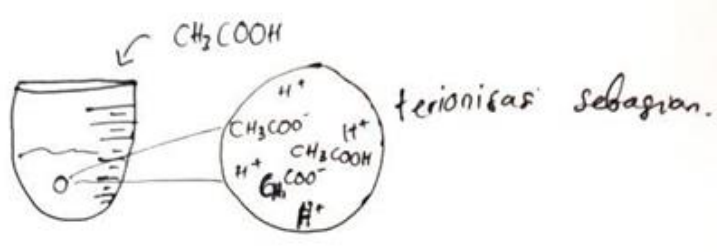

(c)

Gambar 2. Contoh model mental mahasiswa

Berdasarkan uji t, tidak ada perbedaan model mental antara mahasiswa tahun pertama dan tahun kedua dengan nilai signifikansi sebesar 0,861>0,05 yang berarti bahwa pembelajaran di Program Studi Pendidikan Kimia selama 2 tahun belum mampu meningkatkan model mental mahasiswa. Model mental dari sebagian besar mahasiswa tahun pertama dan tahun ketiga juga masih pada level paling rendah, yaitu level inisial. Mahasiswa belum mampu menggambarkan larutan pada level submikroskopik, sehingga mereka tidak mampu menghubungkannya dengan level makroskopik.

Menurut Suja [16] rendahnya model mental mahasiswa disebabkan karena mereka masih mengalami miskonsepi. Miskonsepsi yang terjadi pada mahasiswa adalah menganggap bahwa larutan elektrolit lemah sama dengan larutan elektrolit kuat. Selain itu menurut Dewi, dkk. [17] rendahnya model mental mahasiswa disebabkan rendahnya minat belajar siswa, kurangnya pemahaman siswa tentang termokimia, kurangnya perhatian siswa ketika pembelajaran, metode mengajar yang diterapkan guru tidak menghubungkan tiga level representasi kimia dan padatnya kegiatan di kampus.

\section{Kemampuan Spasial}

Kemampuan spasial sangat dibutuhkan dalam mempelajari kimia karena berkaitan dengan bagaimana memvisualisasikan bentuk molekul dari suatu zat [18]. Kemampuan spasial dibutuhkan ketika mempelajari bentuk molekul, simetri, dll. Dalam penelitian ini, kemampuan spasial diuji menggunakan tes yang dikembangkan oleh Roland Guay (1976).

Hasil penelitian menunjukkan bahwa sebagian besar mahasiswa tahun pertama $(81,25 \%)$ dan tahun ketiga $(79,5 \%)$ memiliki kemampuan spasial yang sangat rendah. Rendahnya kemampuan spasial mahasiswa disebabkan karena kurangnya latihan memvisualisasikan objek 3D terutama yang berkaitan dengan bentuk molekul. Rendahnya kemampuan spasial dapat menyebabkan rendahnya kemampuan mereka dalam menjelaskan level submikroskopik dari suatu zat. Menurut Wu \& Shah [18] kemampuan spasial yang rendah juga dapat meneyebabkan rendahnya hasil belajar mahasiswa.

Berdasarkan analisis uji t, kemampuan spasial mahasiswa tahun pertama dan tahun ketiga tidak berbeda secara signifikan, yaitu dengan nilai signifikansi sebesar $0,328>0,05$. Hal ini berarti bahwa pembelajaran di kelas belum mampu meningkatkan kemampuan spasial mahasiswa. Pembelajaran yang berlangsung selama ini kurang menekankan pada kemampuan spasial.

Oleh karena itu, pembelajaran di kelas perlu diperbaiki. Mahasiswa perlu dilatih untuk menyelesaikan masalah yang berkaitan dengan visual spasial agar mampu menggambarkan molekul secara 3D [18]. Salah satu cara meningkatkan kemampuan spasial mahasiswa menurut Bongers et al. [19] adalah dengan menggunakan animasi 3D dalam menjelaskan konsep kimia.

\section{Hubungan Model Mental dengan Kemampuan Spasial}

Table 3. Model mental model mahasiswa tahun keempat berdasarkan kemampuan spasial

\begin{tabular}{|c|c|c|}
\hline $\begin{array}{c}\text { Kategori } \\
\text { kemampuan } \\
\text { spasial }\end{array}$ & $\begin{array}{c}\text { Persentase } \\
(\%)\end{array}$ & $\begin{array}{c}\text { Kategori } \\
\text { model mental }\end{array}$ \\
\hline Sangat bagus & 0.0 & \\
\hline Bagus & 2.6 & $\begin{array}{l}\text { Model } \\
\text { sintetik }\end{array}$ \\
\hline Di atas rata-rata & 0.0 & \\
\hline Rata-rata & 5.1 & $\begin{array}{l}\text { Model } \\
\text { sintetik }\end{array}$ \\
\hline $\begin{array}{l}\text { Di bawah rata- } \\
\text { rata }\end{array}$ & 2.6 & Model inisial \\
\hline Rendah & 10.3 & Model inisial \\
\hline Sangat rendah & 79.5 & Model inisial \\
\hline
\end{tabular}

Table 4. Model mental model mahasiswa tahun pertama berdasarkan kemampuan spasial

\begin{tabular}{lll}
\hline $\begin{array}{c}\text { Kategori } \\
\text { kemampuan } \\
\text { spasial }\end{array}$ & $\begin{array}{c}\text { Persentase } \\
(\%)\end{array}$ & $\begin{array}{c}\text { Kategori } \\
\text { model mental }\end{array}$ \\
\hline $\begin{array}{l}\text { Sangat bagus } \\
\text { Bagus }\end{array}$ & 0.0 & $\begin{array}{l}\text { Model } \\
\text { sintetik }\end{array}$ \\
Di atas rata-rata & 0.0 & Model \\
Rata-rata & 2.1 & $\begin{array}{l}\text { sintetik } \\
\text { Di bawah rata- }\end{array}$ \\
rata & 8.3 & $\begin{array}{l}\text { Model inisial } \\
\text { Model inisial } \\
\text { Rendah }\end{array}$ \\
$\begin{array}{l}\text { Sangat rendah } \\
\text { Sangat bagus }\end{array}$ & 4.2 & Model inisial \\
\hline
\end{tabular}

Berdasarkan analisis data ditemukan bahwa terdapat hubungan antara model mental dan kemampuan spasial mahasiswa. Kemampuan spasial mempengaruhi model mental dengan nila sig sebesar $0,000<0,05$. Hasil ini sesuai dengan pendapat Harle \& Towns [20] dan Bongers et al. [19] yang menyatakan bahwa kemampuan spasial mempengaruhi model mental. Kemamuan spasial mempengaruhi model mental sebesar $20 \%$ karena 
memilika nilai $\mathrm{R}$ kuadrat sebesar 0,20 , sedangkan sisanya (80\%) dipengaruhi oleh variable lain yang tidak bisa dikontrol oleh peneliti seperti pemahaman, kemampuan berpikir kritis dan lainlain.

Hasil penelitian ini menunjukkan bahwa pembelajaran di kelas belum mampu meningkatkan kemampuan spasial dan model mental mahasiswa.

\section{KESIMPULAN}

Berdasarkan hasil penelitian dapat disimpulkan bahwa model mental dan kemampuan spasial dari sebagian besar mahasiswa berada pada kategori sangat rendah. Model mental dan kemampuan spasial mahasiswa tahun pertama tidak berbeda dengan model mental dan kemampuan spasial mahasiswa tahun ketiga. Hal ini menunjukkan bahwa pembelajaran di kelas belum mampu meningkatkan kemampuan spasial dan model mental mahasiswa. Kemampuan spasial dapat mempengaruhi model mental.

\section{UCAPAN TERIMA KASIH}

Penulis menyampaikan terima kasih kepada Universitas Mataram karena telah mendanai penelitian ini.

\section{DAFTAR PUSTAKA}

[1] Gilbert, J. K., \& Treagust, D. F. (2009). Towards a coherent model for macro, submicro and symbolic representations in chemical education. In Multiple representations in chemical education (pp. 333-350). Springer, Dordrecht.

[2] Jansoon, N., Coll, R. K., \& Somsook, E. (2009). Understanding Mental Models of Dilution in Thai Students. International Journal of Environmental and Science Education, 4(2), 147-168.

[3] Davidowitz, B., Chittleborough, G., \& Murray, E. (2010). Student-generated submicro diagrams: A useful tool for teaching and learning chemical equations and stoichiometry. Chemistry Education Research and Practice, 11(3), 154-164.

[4] Supriadi, S., Ibnu, S., \& Yahmin, Y. (2018). Analisis model mental mahasiswa pendidikan kimia dalam memahami berbagai jenis reaksi kimia. Jurnal Pijar MIPA, 13(1), 1-5.

[5] Devetak, I., Vogrinc, J., \& Glažar, S. A. (2009). Assessing 16-year-old students' understanding of aqueous solution at submicroscopic level. Research in Science Education, 39(2), 157-179.

[6] Cheng, M., \& Gilbert, J. K. (2009). Towards a better utilization of diagrams in research into the use of representative levels in chemical education. In Multiple representations in chemical education (pp.
55-73). Springer, Dordrecht.

[7] Upahi, J. E., \& Ramnarain, U. (2019). Representations of chemical phenomena in secondary school chemistry textbooks. Chemistry Education Research and Practice, 20(1), 146-159.

[8] Akaygun, S. (2016). Is the oxygen atom static or dynamic? The effect of generating animations on students' mental models of atomic structure. Chemistry Education Research and Practice, 17(4), 788-807.

[9] Chittleborough, G. (2004). The role of teaching models and chemical representations in developing students' mental models of chemical phenomena (Doctoral dissertation, Curtin University).

[10] Al-Balushi, S. M., Al-Musawi, A. S., Ambusaidi, A. K., \& Al-Hajri, F. H. (2017). The effectiveness of interacting with scientific animations in chemistry using mobile devices on grade 12 students' spatial ability and scientific reasoning skills. Journal of Science Education and Technology, 26(1), 70-81.

[11] Anggriawan, B., Effendy, E., \& Budiasih, E. (2017). Kemampuan Spasial Dan Kaitannya Dengan Pemahaman Mahasiswa Terhadap Materi Simetri. Jurnal Pendidikan: Teori, Penelitian, dan Pengembangan, 2(12), 1612-1619.

[12] Merchant, Z., Goetz, E. T., KeeneyKennicutt, W., Cifuentes, L., Kwok, O. M., \& Davis, T. J. (2013). Exploring 3-D virtual reality technology for spatial ability and chemistry achievement. Journal of Computer Assisted Learning, 29(6), 579590.

[13] Wahyuni, A., \& Hidayati, D. W. (2020). PENGARUH KEMAMPUAN BERFIKIR KREATIF BERBASIS ICT TERHADAP KEMAMPUAN SPASIAL MAHASISWA. Jurnal Informa, 6(1), 6-9.

[14] Kurnaz, M. A., \& Eksi, C. (2015). An Analysis of High School Students' Mental Models of Solid Friction in Physics. Educational Sciences: Theory and Practice, 15(3), 787-795.

[15] Suari, N. N. J. (2019). PROFIL MODEL MENTAL SISWA TENTANG LARUTAN ELEKTROLIT DAN NONELEKTROLIT. Jurnal Pendidikan Kimia Indonesia, 2(2), 59-63.

[16] Suja, I. W. (2015). Model mental mahasiswa calon guru kimia dalam memahami bahan kajian stereokimia. JPI (Jurnal Pendidikan Indonesia), 4(2).

[17] Dewi, K. M., Suja, I. W., \& Sastrawidana, I. D. K. (2018). Model Mental Siswa Tentang Termokimia. Jurnal Pendidikan Kimia Undiksha, 2(2), 45-52. 
[18] Wu, H. K., Krajcik, J. S., \& Soloway, E. (2001). Promoting understanding of chemical representations: Students' use of a visualization tool in the classroom. Journal of Research in Science Teaching: The Official Journal of the National Association for Research in Science Teaching, 38(7), 821-842.

[19] Bongers, A., Beauvoir, B., Streja, N., Northoff, G., \& Flynn, A. B. (2020). Building mental models of a reaction mechanism: the influence of static and animated representations, prior knowledge, and spatial ability. Chemistry Education Research and Practice, 21(2), 496-512.

[20] Harle, M., \& Towns, M. (2011). A review of spatial ability literature, its connection to chemistry, and implications for instruction. Journal of Chemical Education, 88(3), 351360. 